\title{
PENGARUH METODE PROBLEM SOLVING DAN KESIAPAN BELAJAR SISWA TERHADAP HASIL BELAJAR PAK DI KELAS XI SMA NEGERI 2 BALIGE
}

\author{
Dewi Sartika Sitepu \\ Surel:dewisartika@gmail.com
}

\begin{abstract}
The purpose of this study is to take learning material on Christian attitudes in the development of science. The research subject was 28 students in Class XI of SMA 2 Balige. The results of the study concluded that using the jigsaw method can improve student learning motivation. Increasing student learning motivation in the pre-cycle is 50\%,\% (14 students) to $71.4 \%(20$ students) in Cycle II, to $85.71 \%$ (25 students). As per the data above, it can be interpreted that the motivation to learn has been dominated by some 96.42\% of students. Thus, looking at learning outcomes at the initial observation, there appears to be a significant percentage increase in completeness of student learning outcomes from 50\% (14 students) to $71.4 \%$ (20 students) in Cycle II, to $85.71 \%$ (25 people students), to $96.42 \%$ (27 students).
\end{abstract}

Keywords: Learning Readiness, Problem Solving, Learning Outcomes

\begin{abstract}
ABSTRAK
Tujuan penelitian ini untuk mengambil materi pembelajaran Sikap Kristen dalam pengembangan ilmu pengetahuan. Subjek peneliti ini 28 orang siswa diKelas XI SMA Negeri 2 Balige. Hasil penelitian menyimpulkan bahwa dengan menggunakan metode jigsaw dapat meningkatkan motivasi belajar siswa. Peningkatan motivasi belajar siswa pada pra siklus sebesar 50\%,\% (14 orang siswa) menjadi 71,4\% (20 orang siswa) pada Siklus II, menjadi $85,71 \%$ (25 orang siswa). Sesuai data diatas dapat dimaknai bahwa motivasi belajar sudah didominasi oleh sebagian 96,42\% siswa. Dengan demikian, melihat hasil belajar pada observasi awal, nampak adanya peningkatan persentase yang signifikan ketuntasan hasil belajar siswa dari $50 \%$ (14 orang siswa) menjadi $71,4 \%$ (20 orang siswa) pada Siklus II, menjadi $85,71 \%$ (25 orang siswa), menjadi $96,42 \%$ (27 orang siswa).
\end{abstract}

Kata Kunci : Kesiapan Belajar, Metode Problem Solving, hasil belajar

\section{PENDAHULUAN}

Belajar adalah perubahan yang relatif permanen dalam perilaku atau potensi perilaku sebagai hasil dari pengalaman atau latihan yang diperkuat. Belajar merupakan akibat adanya interaksi antara stimulus dan respon. Seseorang dianggap telah belajar sesuatu jika dia dapat menunjukkan adanya perubahan perilaku. Menurut teori ini dalam belajar yang penting adalah input yang berupa stimulus dan output yang berupa respon. Pada dasarnya belajar merupakan proses perubahan tingkah laku yang berlangsung dalam jangka waktu tertentu melalui memberian pengetahuan, latihan maupun pengalaman. Belajar dengan pengalaman akan membawa pada 
perubahan diri dan cara merespon lingkungan. Faktor-faktor lain yang mempengaruhi kelancaran proses pembelajaran diantaranya adalah kurangnya perhatian peserta didik terhadap materi pembelajaran yang diberikan, bahan ajar yang kurang dipersiapkan, kelengkapan sarana dan prasarana yang kurang memadai.

Kemampuan belajar siswa sangat menentukan keberhasilannya dalam proses belajar. Dalam, proses belajar tersebut, banyak faktor yang dapat mempengaruhi, antara lain tiga faktor utama yang saling mempengaruhi dan berinteraksi dalam proses belajar dan pembelajaran. Seseorang siswa yang suka terhadap perkembangan ilmu pengetahuan biasanya cerderung mengambil pendekatan pembelajaran yang sederhana dan tidak mendalam. Sebaliknya, seorang siswa yang berintelegensi tinggi dan mendapat dorongan positif dari orang tuanya, mungkin akan memilih pendekatan belajar yang lebih mementingkan kualitas hasil belajar dan pembelajaran. Jadi, karena pengaruh fakto-faktor tersebut, muncul siswa yang berprestasi tinggi dan siswa yang berprestasi rendah atu gagal sama sekali. Di sini, guru yang kompeten dan professional diharapkan mampu mengantisipasi kemungkinan munculnya kelompok siswa yang menunjukkan gejala kegagalan dengan berusaha mengetahui dan mengatasi faktor yang mempengaruhi proses belajar dan pembelajaran mereka.
Namun pada kenyataannya kesiapan belajar yang dimiliki siswa SMA Negeri 2 Balige tidaklah seperti yang diharapkan sehingga sangat mempengaruhi hasil belajar. Hal ini di buktikan dengan seringnya beberapa siswa yang tidak mengerjakan PR dan ada bebrapa siswa yang lupa membawa buku pelajaran, sehingga nilai yang diharapkan tidak sesuai dengan kenyataan.

Salah satu metode yang sesuai untuk mata pelajaran agama kristen adalah metode problem solving (Pemecahan masalah). Dalam metode ini guru PAK dapat melibatkan keaktifan siswa didalam kelas. Metode problem solving (pemecahan masalah) adalah penggunaan metode dalam kegiatan pembelajaran dengan jalan melatih siswa menghadapi berbagai masalah baik itu masalah pribadi maupun masalah kelompok untuk dipecahkan secara bersama-sama. Penyelesaian masalah merupakan proses dari menerima tantangan dan usaha untuk menyelesaikannya sampai menemukan penyelesaian. Metode problem solving bukan hanya sekedar metode mengajar tetapi juga merupakan suatu metode berpikir, sebab dalam problem solving dapat menggunakan metode lain yang dimulai dari mencari data sampai kepada menarik kesimpulan.

\section{METODE PENELITIAN}

Tempat penelitian ini dilaksanakan oleh peneliti di Kelas XI SMA Negeri 2 Balige. alasan 
penulis memilih sekolah ini sebagai tempat penelitian. Adapun waktu penelitian ini dilaksanakan selama dua bulan. Yaitu bulan Mei sampai bulan Juni 2018, kegiatan peneliti terdiri dari kegiatan izin penelitian, pengumpulan data, analisi data, penyusunan konsep laporan dan diakhiri penyampaian hasil laporan peneliti.

Subjek penelitian ini adalah siswa kelas Kelas XI SMA Negeri 2 Balige, dengan jumlah siswa sebanyak 28 orang. Objek penelitian ini adalah upaya peningkatan motivasi belajar siswa pada mata pelajaran pendidikan agama Kristen melalui metode metode problem solving di Kelas XI SMA Negeri 2 Balige.

Metode

penelitian

menggunakan metode Penelitian Tindakan Kelas dengan tiga siklus. Menurut metode tersebut, pelaksanaan penelitian mencakup empat tahap yaitu: Perencanaan (Plan), Tindakan (Act), pengamatan (Observe), Refleksi (Reflect). Dalam metode deskriptif adalah metode penelitian yang ditunjukkan kepada pemecahan masalah.

Tehnik pengumpulan data merupakan langkah yang paling strategis dalam tindakan penelitian, karena tujuan utama seseorang untuk melakukan penelitian adalah untuk memperoleh data. Tanpa tehnik pengumpulan data maka seorang peneliti tidak akan mendapat data yang memenuhi standart yang ditetapkan. Untuk melihat peningkatan yang terjadi dalam proses pembelajaran yang sedang berlangsung.

\section{HASIL PENELITIAN DAN PEMBAHASAN}

Lokasi penelitian pembelajaran adalah di Kelas XI SMA Negeri 2 Balige. Mata pelajaran Pendidikan Agama Kristen dengan Metode metode problem solving Penelitian dilaksanakan dalam tiga siklus, siklus I pada tanggal 8 Mei 2018, siklus II pada tanggal 20 Mei 2018, dan Siklus ketiga pada tanggal 30 Mei 2018 dan sesuai dengan jadwal kegiatan. Penelitian ini di bantu oleh teman sejawat sebagai rekan kerja dan pengamat dalam penelitian ini. Subyek penelitian tindakan Kelas XI ini adalah dengan jumlah siswa 28 siswa. Hasil penelitian diuraikan dalam tahapan yang berupa siklussiklus pembelajaran yang dilakukan sebagai berikut:

Hasil penelitian siklus I menyajikan laporan hasil-hasil setiap tahapan penelitian tindakan kelas, mulai perencanan, pelaksanaan tindakan, observasi dan evaluasi, dan refleksi.

Penyusunan RPP (Rencana Perbaikan Pembelajaran) untuk observasi proses belajar mengajar yang bisa dilakukan guru, pada pelajaran Pendidikan Agama Kristen.

Kegiatan selanjutnya terdiri dari kegiatan merumuskan tujuan pembelajaran, menyusun langkahlangkah dalam pembelajaran, merencanakan alat yang sesuai 
Dewi Sartika Sitepu: Pengaruh Metode Problem Solving...

dengan pokok bahasan yang akan diajarkan.

a. Mempersiapkan daftar pengamatan sebagai acuan untuk mengumpulkan data tentang prestasi belajar siswa dalam mengikuti pelajaran Pendidikan Agama Kristen serta menyiapkan bahan penelitian.

b. Mempersiapkan tes di akhir pelajaran yang dimaksudkan untuk mengetahui perkembangan prestasi.

c. Pelaksanaan Perbaikan

Pada pelaksanaan tindakan pada siklus I, peneliti bertindak sebagai guru dibantu oleh teman sejawat sebagai pengamat yang memantau jalannya proses pembelajaran.

Guru melaksanakan pembelajaran dengan menggunakan metode metode problem solving untuk meningkatkan Motivasi belajar dimana guru menggunakan media yang mendukung sesuai dengan materi yang disampaikan, guru kemudian memberikan pertanyaanpertanyaan dan tugas-tugas sehingga siswa dapat menjawab pertanyaanpertanyaan yang diajukan guru.

Selama proses pembelajaran, peneliti dibantu teman sejawat untuk melakukan pengumpulan data dengan cara mencatat kejadiankejadian Untuk mengetahui peningkatan motivasi belajar siswa dalam mengikuti pelajaran dengan topik "Sikap Kristen dalam Pengembangan Ilmu Pengetahuan" yang dilakukan dengan menerapkan metode permbelajaran metode problem solving maka digunakan rumus seperti berikut:

Persentase $=\frac{\text { Skor Perolehan } \times 100 \%}{\text { Skor Maksimal }}$

Kategori Penilaian Tingkat Keaktifan $90 \%-100 \% \quad$ Sangat Aktif $75 \%-89 \% \quad$ Aktif $55 \%-74 \% \quad$ Kurang Aktif $35 \%-54 \% \quad$ Tidak Aktif $0 \%-34 \% \quad$ Sangat Tidak Aktif

Kegiatan pengamatan siklus I, dilakukan untuk mengetahui peningkatan motivasi siswa dalam proses belajar mengajar berlangsung dengan menggunakan metode Jigsaw.

Tabel 1. Perolehan Tingkat Keaktifan Siswa

\begin{tabular}{c|c|c|c}
\hline Kategori & Frekuensi & $\begin{array}{c}\text { Persentase } \\
\text { Frekuensi }\end{array}$ & $\begin{array}{c}\text { Tingkat } \\
\text { Keaktifan }\end{array}$ \\
\hline $\begin{array}{c}\mathbf{9 0 \%}- \\
\mathbf{1 0 0 \%}\end{array}$ & 2 & $7,14 \%$ & $\begin{array}{c}\text { Sangat } \\
\text { Aktif }\end{array}$ \\
\hline $\begin{array}{c}\mathbf{7 5 \%}- \\
\mathbf{8 9 \%}\end{array}$ & 7 & $25 \%$ & Aktif \\
\hline $\mathbf{5 5 \%}-$ & 6 & $21,4 \%$ & $\begin{array}{c}\text { Kurang } \\
\text { Aktif }\end{array}$ \\
\hline $\mathbf{7 4 \%}$ & & $25 \%$ & $\begin{array}{c}\text { Tidak } \\
\text { Aktif }\end{array}$ \\
\hline $\mathbf{3 5 \%}-$ & 7 & $21,4 \%$ & $\begin{array}{c}\text { Sangat } \\
\text { Tidak } \\
\text { A4\% }\end{array}$ \\
\hline $\mathbf{0 \% -}$ & 6 & & Aktif \\
$\mathbf{3 4 \%}$ & & &
\end{tabular}

Tabel di atas menunjukkan bahwa siswa yang sangat aktif 2 orang $(7,14 \%)$, siswa yang aktif 7 orang (25\%), siswa yang kurang aktif 6 orang $(21,4 \%)$, siswa yang tidak aktif 7 orang (25\%) dan siswa yang sangat tidak aktif 6 orang $(21,4 \%)$.

Dari frekuensi perolehan data tersebut di atas, dapat disimpulkan bahwa rata-rata tingkat keaktifan 
siswa adalah kurang aktif. Hal itu dapat dilihat dari rata-rata persentase perolehan keaktifan siswa sebesar $57,7 \%$, yaitu berada pada kategori kurang aktif.

Grafik 1.

\section{Perolehan Tingkat Keaktifan Siswa}

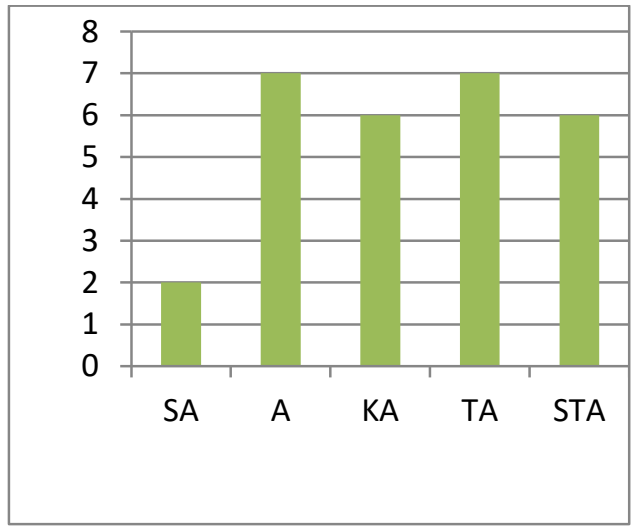

Keaktifan siswa selama proses pembelajaran pada siklus I ini belum menunjukkan hasil yang maksimal. Hal ini disebabkan oleh beberapa hal, seperti:

a. Siswa kurang termotifasi untuk belajar Pendidikan Agama kristen

b. Metode yang diterapkan guru masih belum bisa membuat siswa aktif dalam pembelajaran di kelas karena

Tabel 2. Perbandingan kondisi awal dan Siklus I

\begin{tabular}{|c|c|c|c|c|c|c|}
\hline \multirow{2}{*}{ No } & \multirow{2}{*}{ Uraian } & \multirow{2}{*}{$\begin{array}{c}\text { Jmlh } \\
\text { Siswa }\end{array}$} & \multicolumn{2}{|c|}{$\begin{array}{l}\text { Siswa } \\
\text { Belum } \\
\text { Tuntas }\end{array}$} & \multicolumn{2}{|c|}{$\begin{array}{l}\text { Siswa } \\
\text { Tuntas }\end{array}$} \\
\hline & & & $\begin{array}{c}\text { Fre } \\
\text { k. }\end{array}$ & $\%$ & $\begin{array}{c}\text { Fre } \\
\text { k. }\end{array}$ & $\%$ \\
\hline 1 & Awal & 28 & 14 & 50 & 14 & 50 \\
\hline 2 & Siklus I & 28 & 20 & $\begin{array}{c}71, \\
4\end{array}$ & 8 & $\begin{array}{l}28, \\
57\end{array}$ \\
\hline
\end{tabular}

Data yang telah dikumpulkan melalui tes menunjukkan masih banyak siswa yang belum mencapai nilai ketuntasan belajar. Dari tabel di atas dapat diketahui bahwa jumlah siswa yang sudah mencapai nilai ketuntasan adalah 20 orang dengan persentase $71,4 \%$, sedangkan yang belum tuntas sebanyak 8 orang dengan persentase $28,7 \%$. Perolehan persentase ketuntasan belajar tersebut dapat ditunjukkan pada grafik berikut:

\section{Grafik 2. Perolehan Persentase Ketuntasan Belajar Siswa}

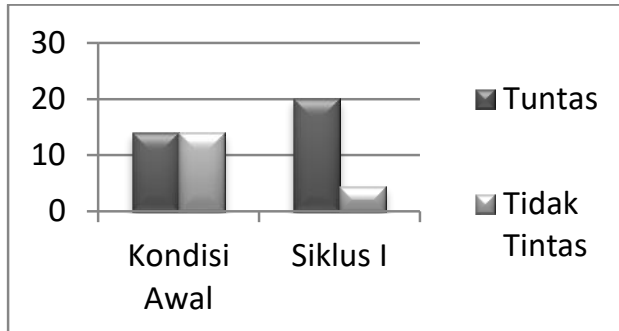

Sesuai data di atas, dapat dimaknai bahwa Motivasi belajar sudah didominasi oleh sebagian besar siswa. Namun demikian, melihat hasil belajar pada observasi awal, nampak adanya peningkatan persentase ketuntasan hasil belajar siswa dari $50 \%$ (14 orang siswa) menjadi $71,4 \%$ (20 orang siswa).

Hasil penelitian siklus I menyajikan laporan hasil-hasil setiap tahapan penelitian tindakan kelas, mulai perencanan, pelaksanaan tindakan, observasi dan evaluasi, dan refleksi. Setelah mempertimbangkan hasil refleksi pada siklus pertama, maka pada siklus kedua peneliti mencoba unutk menyempurnakan 
pelaksanaan perbaikan pembelajaran. Berdasarkan hasil tindakan I, faktor yang diduga menjadi penyebab timbulnya permasalahan tersebut adalah metode yang dipakai kurang bisa membantu siswa untuk menuangkan idenya karena siswa baru mengenal metode pembelajaran metode problem solving.

a. Penyusunan RPP (Rencana Perbaikan Pembelajaran) untuk observasi proses belajar mengajar yang bisa dilakukan guru, pada pelajaran Pendidikan Agama Kristen.

b. Kegiatan selanjutnya terdiri dari kegiatan merumuskan tujuan pembelajaran, menyusun langkah-langkah pembelajaran, merencanakan alat yang sesuai dengan pokok bahasan yang akan diajarkan.

c. Mempersiapkan daftar pengamatan sebagai acuan untuk mengumpulkan data tentang prestasi belajar siswa dalam mengikuti pelajaran Pendidikan Agama Kristen serta menyiapkan bahan penelitian.

d. Mempersiapkan tes di akhir pelajaran yang dimaksudkan untuk mengetahui perkembangan prestasi.

Tindakan II dilakukan dengan menggunakan strategi tanya jawab. Pelaksanaan sama degan tindakan I dalam kegiatan awal. Kegiatan inti pada tindakan II ini adalah memberikan pertanyaan pada siswa. Selanjutnya siswa dalam kelompok untuk berdiskusi tentang hal yang didapatkannya. Setelah itu siswa menyampaikan hasil diskusinya dan dilanjutkan dengan tanya jawab.

Pada waktu guru mengajar, peneliti dibantu teman sejawat untuk melakukan pengumpulan data dengan cara mencatat kejadiankejadian selama kegiatan pembelajaran berlangsung untuk mengetahui sejauh mana Motivasi belajar siswa sebelum dan sesudah diberi tindakan.Untuk mengetahui perkembangan prestasi belajar siswa dilakukan melalui tes yang diberikan diakhir siklus.

Kegiatan pengamatan siklus II, dilakukan untuk mengetahui peningkatan motivasi belajar siswa siswa dalam proses belajar mengajar berlangsung dengan menggunakan metode metode problem solving Untuk memudahkan peneliti dalam mengumpulkan data tentang peningkatan motivasi belajar siswa, maka peneliti membuat tabel pedoman penilaian peningkatan motivasi belajar siswa, seperti berikut:

Persentase $=\frac{\text { Skor Perolehan } \times 100 \%}{\text { Skor Maksimal }}$

Keterangan:

Kategori Penilaian Tingkat Keaktifan $90 \%-100 \% \quad$ Sangat Tinggi $75 \%-89 \% \quad$ Tinggi

$55 \%-74 \% \quad$ Normal

35\% - 54\% Rendah

$0 \%-34 \% \quad$ Sangat Rendah

Kegiatan pengamatan siklus II ini dilakukan untuk mengetahui lebih lanjut bagaimana peningkatan 
motivasi belajar siswa selama proses belajar mengajar berlangsung dengan menggunakan metode metode problem solving Persentase keaktifan siswa yang diperoleh seperti terdapat pada tabel di atas, kemudian dibandingkan dengan kategori penilaian tingkat keaktifan siswa yang telah ditentukan sebelumnya, sebagai berikut:

Tabel 3. Frekuensi Tingkat Keaktifan Siswa Siklus II

\begin{tabular}{cccc}
\hline Kategori & Frekuensi & $\begin{array}{c}\text { Persentase } \\
\text { Frekuensi }\end{array}$ & $\begin{array}{c}\text { Tingkat } \\
\text { Keaktifan }\end{array}$ \\
\hline $\begin{array}{c}90 \%- \\
100 \%\end{array}$ & 5 & $17,8 \%$ & $\begin{array}{c}\text { Sangat } \\
\text { Aktif }\end{array}$ \\
\hline $\begin{array}{c}75 \%- \\
89 \%\end{array}$ & 7 & $25 \%$ & Aktif \\
\hline $\begin{array}{c}55 \%- \\
74 \%\end{array}$ & 12 & $42,8 \%$ & $\begin{array}{c}\text { Kurang } \\
\text { Aktif }\end{array}$ \\
\hline $\begin{array}{c}35 \%- \\
54 \%\end{array}$ & 4 & 14,2 & $\begin{array}{c}\text { Tidak } \\
\text { Aktif }\end{array}$ \\
\hline $0 \%-$ & 0 & $\%$ & $\begin{array}{c}\text { Sangat } \\
\text { Tidak } \\
34 \%\end{array}$ \\
& & & Aktif \\
\hline
\end{tabular}

Tabel di atas menunjukkan bahwa siswa yang sangat aktif 5 orang $(17,8 \%)$, siswa yang aktif 7 orang $(25 \%)$, siswa yang kurang aktif 12 orang $(42,8 \%)$, siswa yang tidak aktif 4 orang $(12,8 \%)$ dan siswa yang sangat tidak aktif 0 orang (0\%).Dari frekuensi perolehan data tersebut di atas, dapat disimpulkan bahwa ratarata tingkat keaktifan siswa adalah kurang aktif. Hal itu dapat dilihat dari rata-rata persentase perolehan keaktifan siswa sebesar $70,5 \%$, yaitu masih berada pada kategori kurang aktif.

Akan tetapi bila dibandingkan hasil rata-rata persentasi dari siklus I ke siklus II sudah terjadi peningkatan, dimana rata-rata persentase peningkatan motivasi belajar siswa pada siklus I adalah $57,7 \%$ sedang pada siklus II rata-ratanya adalah $70,5 \%$.

Dari hasil observasi, dilakukan analisis pada tindakan II kemudian dilanjutkan dengan refleksi yang dilakukan bersama teman sejawat. Hasil observasi pada siklus ke II ini belum menunjukkan hasil yang maksimal. Tetapi sudah terjadi peningkatan motivasi dari siklus I ke siklus II. Adapun hasil analisis tindakan II diketahui sebagai berikut:

a. Siswa mulai mampu mengungkapkan pendapatnya lewat tanya jawab.

b. Siswa mulai terbiasa bertukar pikiran dengan temannya.

c. Keberanian siswa untuk mengeluarkan ide dan gagasannya baik pada waktu tanya jawab berlangsung mulai meningkat.

d. Dorongan dan bimbingan kepada siswa perlu ditingkatkan karena masih ada siswa yang kurang semangat dalam mengikuti pelajaran.

Hasil analisis pada siklus II ini sudah menunjukkan adanya peningkatan motivasi belajar belajar. Hasil tes menunjukkan bahwa telah terjadi peningkatan ketuntasan hasil belajar siswa. Tetapi belum menunjukkan hasil yang maksimal. Oleh sebab itu diperlukan tindakan selanjutkan untuk memperbaiki kesalahan/kelemahan pada siklus II ini. 
Siklus III ini merupakan upaya perbaikan dari siklus sebelumnya. Jadi sebagaimana pada perencanaan siklus I dan II, perencanaan dalam siklus ini dituangkan dalam bentuk Silabus dan Rencana Pelaksanaan Pembelajaran (RPP) yang dibuat dengan merujuk kepada Metode metode problem solving. Menetapkan Sumber belajar merujuk pada hasil pengamatan siswa di lapangan dan buku paket mata pelajaran serta. Menyiapkan format wawancara yang akan digunakan peneliti untuk mengetahui keefektifan penggunaan metode metode problem solving dalam meningkatkan motivasi belajar siswa. Pertanyaan-pertanyaan wawancara tersebut akan diajukan kepada kolaborator yang bertindak sebagai pengamat, baik sebagai pengamat keaktifan belajar siswa maupun sebagai pengamat penerapan metode jigsaw pada mata pelajaran Pendidikan Agama Kristen.

Berdasarkan hasil yang dicapai pada tindakan kelas siklus II maka rencana tindakan kelas siklus II perlu direvisi yang hasilnya akan digunakan sebagai acuan pelaksanaan tindakan kelas siklus III. Beberapa revisi yang disepakati dengan guru kelas yaitu: Prosedur pembelajaran diupayakan lebih menarik lagi agar aktifitas dan efikasi diri siswa semakin meningkat.

Guru lebih mengoptimalkan pemberian motivasi untuk meningkatkan aktivitas belajar siswa. Proses pembelajaran harus berpusat pada siswa. Guru berusaha mendorong semua siswa agar berpartisipasi secara aktif dalam menjawab pertanyaan pada saat pembelajaran berlangsung.

Pelaksanaan pada tindakan III ini sama dengan tindakan I dan II. Namun pada pelaksanaan tindakan III ini peneliti menggunakan strategi tanya jawab dengan jumlah kelompok yang lebih kecil agar mereka bisa mengungkapkan pendapatnya dengan lebih baik. Dengan melihat dari pelaksanaan tindakan I dan II maka dalam tindakan III ini, diharapkan bisa memberi peningkatan yang signifikan terhadap efikasi diri siswa dalam proses belajarnya. Peneliti dan guru melakukan pengamatan terhadap penerapan Metode metode problem solving dalam meningkatkan pemahaman siswa yang tujuannya adalah efikasi diri, Peneliti juga mengamati perubahan yang terjadi pada tindakan III.

Persentase $=\frac{\text { Skor Perolehan } \times 100 \%}{\text { Skor Maksimal }}$

Kategori Penilaian Tingkat Keaktifan $90 \%-100 \% \quad$ Sangat Tinggi $75 \%-89 \% \quad$ Tinggi $55 \%-74 \% \quad$ Normal $35 \%-54 \% \quad$ Rendah 0\% $-34 \% \quad$ Sangat Rendah

Motivasi belajar siswa pada sisklus III ini sudah semakin meningkat daripada siklus sebelumnya. Hal tu terlihat dari perolehan persentase tingkat 
keaktifan siswa seperti terlihat pada tabel di atas. Persentase keaktifan siswa yang diperoleh seperti terdapat pada tabel di atas, kemudian dibandingkan dengan kategori penilaian tingkat keaktifan siswa yang telah ditentukan sebelumnya, sebagai berikut:

Tabel 4. Frekuensi Tingkat Keaktifan Siswa Siklus III

\begin{tabular}{cccc}
\hline Kategori & Frek. & $\begin{array}{c}\% \\
\text { Frek. }\end{array}$ & $\begin{array}{c}\text { Tingkat } \\
\text { Keaktifan }\end{array}$ \\
\hline $\begin{array}{c}\text { 90\%- } \\
100 \%\end{array}$ & 5 & $17,8 \%$ & $\begin{array}{c}\text { Sangat } \\
\text { Aktif }\end{array}$ \\
\hline $\begin{array}{c}75 \%- \\
89 \%\end{array}$ & 7 & $25 \%$ & Aktif \\
\hline $55 \%-$ & 12 & $42,8 \%$ & $\begin{array}{c}\text { Kurang } \\
\text { Aktif }\end{array}$ \\
$74 \%$ & & & Tidak \\
$35 \%-$ & 4 & 14,2 & Aktif \\
$54 \%$ & & & Sangat \\
& & & Tidak \\
& & & Aktif \\
\hline $34 \%$ & 0 & &
\end{tabular}

Dari tabel di atas, dapat diketahui bahwa tingkat motivasi belajar siswa berada pada kategori aktif. Hal itu dapat dilihat dari persentase tingkat keaktifan siswa yang sangat aktif dan aktif masingmasing adalah $21,42 \%$ dan $50 \%$. Hal ini berarti bahwa telah terjadi peningkatan yang positif dan signifikan dari keaktifan belajar siswa dari siklus sebelumnya, dimana tingkat keaktifan belajar siswa pada siklus II berada kategori kurang aktif.

Peningkatan keaktivan belajar siswa dapat dibuat dalam bentuk grafik seperti berikut:
Grafik 3. Perolehan Tingkat Keaktifan SiswaPerolehan Tingkat Keaktifan Siswa

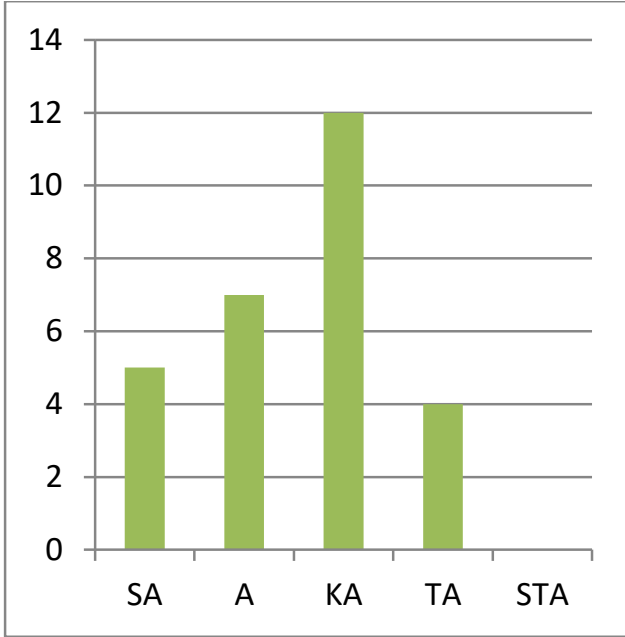

Dari hasil observasi, dilakukan analisis pada tindakan III kemudian dilanjutkan dengan refleksi yang dilakukan bersama teman sejawat. Pada siklus III, peniliti bersama dengan kolaborator melihat bahwa telah terjadi peningkatan motivasi belajar siswa dari siklus sebelumnya. Berikut ini merupakan perbandingan persentase frekuensi ketuntasan siswa mulai dari pra tindakan hingga siklus.

\section{Grafik 4. Perbandingan Persentase Frekuensi Ketuntasan Siswa}

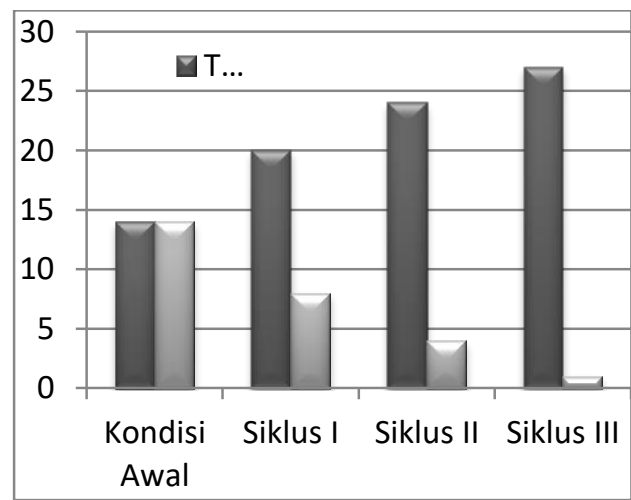


Sesuai data di atas, dapat dimaknai bahwa Motivasi belajar sudah didominasi oleh sebagian 96,42\% siswa.Dengan demikian, melihat hasil belajar pada observasi awal, nampak adanya peningkatan persentase yang signifikan ketuntasan hasil belajar siswa dari $50 \%$ (14 orang siswa) menjadi $71,4 \%$ (20 orang siswa) pada Siklus II, menjadi $85,71 \%$ (25 orang siswa), menjadi $96,42 \%$ (27 orang siswa).

\section{SIMPULAN}

Berdasarkan analisis data dan hasil penelitian tindakan kelas (Classroom Action Research) yang dilakukan dapat disimpulkan bahwa: Penggunaan pembelajaran metode jigsaw dapat meningkatkan motivasi belajar siswa Kelas XI SMA Negeri 2 Balige Hasil observasi keaktifan belajar siswa dari siklus I hingga siklus III menunjukkan terjadinya peningkatan motifasi belajar pada mata pelajaran Pendidikan Agama Kristen. Dari siklus I ke siklus II terjadi peningkatan sebesar 12,8\%, dimana rata-rata keaktifan belajar siswa pada siklus I dan siklus II masing-masing adalah $57,7 \%$ dan 70,5\%. Dari siklus II ke siklus III terjadi peningkatan sebesar 5,9\%, dimana rata-rata keaktifan belajar siswa pada siklus III adalah $76,4 \%$.

Hasil peningkatan motivasi belajar siswa juga dibuktikan dengan melihat membandingkan hasil belajar siswa pada setiap siklus. Melihat hasil belajar pada observasi awal, nampak adanya peningkatan persentase ketuntasan hasil belajar siswa dari $50 \%$ (14 orang siswa) menjadi $71,4 \%$ (20 orang siswa) pada Siklus II, menjadi 85,71\% (25 orang siswa). Sesuai data diatas dapat dimaknai bahwa motivasi belajar sudah didominasi oleh sebagian 96,42\% siswa. Dengan demikian, melihat hasil belajar pada observasi awal, nampak adanya peningkatan persentase yang signifikan ketuntasan hasil belajar siswa dari $50 \%$ (14 orang siswa) menjadi $71,4 \%$ (20 orang siswa) pada Siklus II, menjadi $85,71 \%$ (25 orang siswa), menjadi $96,42 \%$ (27 orang siswa).

\section{DAFTAR RUJUKAN}

Dimyati, Mudjiono. 2006. Belajar dan Pembelajaran. Jakarta: PT Rineka Cipta.

Lilik, Kristanto Paulus. 2006. Prinsip dan Praktek PAK Penuntun Bagi Mahasiswa Teologi dan Pak, Pelayan Gereja, Guru Agama dan Kluarga Kristen. Yogyakarta: Andi.

Mukhtar. 2007. Bimbingan Skripsi, Tesis, dan Artikel Ilmiah: Panduan Berbasis Kualitatif Lapangan Dan Perpustakaan. Jakarta: Gaung Persada Pres.

Suharsimi, Arikunto. 2006. Prosedur Penelitian Suatu Pendekatan Praktik. Jakarta: PT Rineka Cipta.

W, Gulo. 2010. Strategi Belajar Mengajar. Jakarta: Grasindo. 